\title{
IMPLEMENTASI KEGIATAN BERMAIN OUTDOOR DALAM MENGEMBANGKAN MOTORIK KASAR DI TK PKK BANJARJO PUDAK PONOROGO
}

\author{
Ririn \\ Institut Agama Islam Negeri Ponorogo \\ Email: ririnindah187@gmail.com \\ Yuli Salis Hijriyani \\ Institut Agama Islam Negeri Ponorogo \\ Email: hijriyani@iainponorogo.ac.id
}

\begin{abstract}
Physical-motor development is physical development through coordinated nerve center, nerve, and muscle activities. Before the development of motor movement begins to process, then the child will remain helpless. The objectives of this study are: 1) The forms of outdoor play activities in TK PKK Banjarjo Pudak Ponorogo. 2) Implementation of outdoor play activities in developing gross motor skills in TK PKK Banjarjo Pudak Ponorogo. 3) Supporting and inhibiting factors in implementing outdoor play activities to develop gross motor skills in PKK Banjarjo Kindergarten, Pudak Ponorogo. The research approach used is qualitative research with a type of case study research. Data collection techniques in this study used observation, interview, and documentation techniques. The data analysis technique follows the concepts put forward by Miles and Huberman namely data reduction, data presentation, and conclusion drawing. From the analysis of the data it was concluded that: 1) The forms of outdoor play activities included playing outside APE such as seesaw, globe and swing, gymnastics using music, playing traditional games such as crickets, stilts and snakes, observing plants and imitating animal paths. 2) Implementation of outdoor play activities in developing gross motor skills by exercising using music every day if the yard is not wet and playing outside APE such as seesaw, globe and swing every day at rest.3) Supporting factors in implementing outdoor play activities to develop gross motor skills that is the enthusiasm of children participating in learning with enthusiasm, besides that the motivation of school principals and teacher cohesiveness to achieve common goals while the inhibiting factor in implementing outdoor play activities to develop gross motor skills is the inadequate funding and yard factors.
\end{abstract}

Keywords: Motor Physical Development, Rough Motor, Outdoor Games

Abstrak: Perkembangan fisik-motorik adalah perkembangan jasmani melalui kegiatan pusat saraf, urat saraf, dan otot yang terkoordinasi. Sebelum perkembangan gerak motorik ini mulai berproses, maka anak akan tetap tak berdaya.Tujuan Penelitian ini adalah: 1) Bentuk-bentuk kegiatan bermain outdoor di TK PKK Banjarjo Pudak Ponorogo. 2) Implementasi kegiatan bermain outdoor dalam mengembangkan motorik kasar di TK PKK Banjarjo Pudak Ponorogo. 3) Faktor pendukung dan penghambat dalam mengimplementasikan kegiatan bermain outdoor untuk mengembangkan motorik kasar di TK PKK Banjarjo Pudak Ponorogo. Pendekatan penelitian yang digunakan adalah penelitian kualitatif dengan jenis penelitian studi kasus. Teknik pengumpulan data dalam penelitian ini menggunakan teknik observasi, wawancara, dan dokumentasi. Adapun teknik analisis data mengikuti konsep yang dikemukakan oleh Miles dan Huberman yaitu reduksi data, penyajian data, dan penarikan kesimpulan. Dari analisis data disimpulkan bahwa: 1) Bentuk-bentuk kegiatan bermain outdoor meliputi bermain APE luar seperti jungkat-jungkit, bola dunia dan ayunan, senam menggunakan musik, 
bermain permainan tradisional seperti engklek, egrang dan ular naga, mengamati tanaman dan menirukan jalan binatang. 2) Implementasi kegiatan bermain outdoor dalam mengembangkan motorik kasar yaitu dengan cara senam menggunakan musik setiap hari apabila halaman tidak basah dan bermain APE luar seperti jungkat-jungkit, bola dunia dan ayunan setiap hari pada saat istirahat.3) Faktor pendukung dalam mengimplementasikan kegiatan bermain outdoor untuk mengembangkan motorik kasar yaitu semangat anak-anak mengikuti pembelajaran dengan antusias, selain itu juga motivasi dari kepala sekolah dan kekompakan guru untuk mencapai tujuan bersama sedangkan faktor penghambat dalam mengimplementasikan kegiatan bermain outdoor untuk mengembangkan motorik kasar adalah faktor pembiayaan dan halaman yang kurang memadai.

\section{Kata Kunci: Perkembangan Fisik Motorik, Motorik Kasar, Permainan Outdoor}

\section{PENDAHULUAN}

Kegiatan bermain outdoor adalah aktivitas yang dilakukan anak dengan menyenangkan di luar ruangan. Berdasarkan kebutuhan perkembangan, lembaga pendidikan memerlukan acuan sarana bagi terlaksananya pendidikan pada anak usia dini. Kebutuhan perkembangan anak dapat dipenuhi dengan kegiatan bermain di luar ruangan. Kebutuhan bermain anak di luar ruangan tidak hanya terbatas pada alat permainan yang disediakan di halaman saja, tetapi dapat pula memanfaatkan sarana yang ada di lingkungan sekitar.

Sedangkan Alat Permainan Edukatif (APE) Outdoor adalah sarana bermain yang berada di luar ruangan. Alat ini dapat digunakan sebagai alat bantu pembelajaran, sarana bermain yang mengandung nilai pendidikan (edukasi) dan dapat mengembangkan seluruh aspek tumbuh kembang pada anak usia dini. APE outdoor ini dapat bermanfaat untuk menunjang atau menstimulasi tumbuh kembang sesor motorik kasar anak, sosial anak, dan psikis anak. Biasanya anak-anak yang bermain di luar ruangan akan cenderung mempunyai daya tahan tubuh yang kuat, dibandingkan dengan anak-anak yang lebih sering bermain didalam ruangan. Alat ini juga dapat berguna bagi tumbuh kembang kelima panca indera anak. ${ }^{1}$ APE outdoor antara lain:

${ }^{1}$ https://www.paud.id/2015/09/pengertian-sarana-bermain-luar-ruangan-aud.html 
1) Bermain Perosotan merupakan kegiatan outdoor yang banyak dijumpai di taman bermain anak-anak. Bermain dengan APE perosotan ini bisa dibuat sendiri dengan menggunakan bahan utama pasir dan semen. namun sekarang sudah tersedia alat permainan perosotan yang terbuat dari bahan plastik maupun logam yang bisa dibeli secara langsung di toko-toko mainan. APE perosotan idealnya digunakan untuk anak usia 3 sampai 6 tahun. Cara menggunakan alat permainan ini sangatlah mudah, karena anak tinggal naik ke atas menggunakan tangga yang tersedia kemudian duduk di papan tumpuan dan meluncur dari atas ke bawah. Manfaat dari alat permainan perosotan bagi perkembangan anak ialah dapat melatih motorik kasar anak, ketangkasan, konsentrasi, dan kreativitas. ${ }^{2}$

2) Bermain Ayunan yaitu terdiri dari papan sebagai tempat duduk dan dua pasang tali atau rantai sebagai pengikat untuk dihubungkan ke tiang penyangga. Ayunan bisa dibuat dengan besi atau bahan yang lain, seperti ban bekas, kayu, dan plastik namun sekarang ini sudah tidak perlu repot-repot membuatnya, karena sudah banyak dijual di toko-toko mainan anak outdoor. Ayunan sangat cocok digunakan untuk anak usia 4-6 tahun. Cara menggunakan alat permainan ini yaitu dengan cara menduduki ayunan tersebut, kemudian diayun perlahan-lahan pada saat diayunkan anak harus berpegangan pada tali atau rantai pengikat dan menjaga keseimbangan supaya tidak terjatuh saat di kan biasanya ayunan dimainkan secara berpasangan satu orang duduk di ayunan dan yang satu bertugas Mengayunkan demikian ini dilakukan secara bergantian sampai selesai. Adapun manfaat dari menggunakan alat permainan ayunan yaitu dapat melatih motorik kasar anak, melatih keseimbangan, konsentrasi dan ketangkasan anak.

2 M. Fadlillah, Bermain Dan Permainan Anak Usia Dini, (Jakarta: Kencana, 2017), 90. 
3) Bermain Jungkat-jungkit merupakan alat permainan yang berupa batangan besi maupun kayu berukuran Kurang lebih 3 meter yang di tengah- tengahnya diberikan tumpuan yang tingginya kurang lebih 60 $\mathrm{cm}$. Kemudian di masing-masing ujung batang besi atau kayu tersebut diberikan dudukan dan pegangan untuk anak.Alat permainan ini cocok digunakan untuk anak usia 4 sampai 6 tahun.Namun bisa juga digunakan untuk anak 2 sampai 3 tahun tetapi membutuhkan dan dengan orang yang lebih dewasa. Cara menggunakan alat pemanen ini, yaitu dengan menduduki di masing- masing ujung besi atau kayu, kemudian masing-masing anak saling menggenjot supaya terjadi gerakan ke atas dan ke bawah.Jadi alat permainan ini digunakan secara berpasangan, minimal dua anak. Adapun manfaat dari bermain jungkat- jungkit bagi anak ialah dapat mengembangkan kinestetik, konsentrasi, keseimbangan dan kelincahan anak. Selain itu dapat menguatkan otot tangan dan kaki anak.

4) Bermain Jembatan goyang merupakan kegiatan bermain dengan menggunakan alat permainan outdoor yang terbuat dari besi cara pembuatan alat permainan ini cukup rumit dan membutuhkan keahlian khusus. Namun demikian, alat permainan jembatan goyang ini bisa didapatkan di industri industri pembuatan alat outdoor.. Untuk harganya sangat relatif tergantung ukuran, kerumitan, dan bahan yang digunakan.Tetapi rata-rata alat permainan yang satu ini harganya mencapai 2 juta per unit. Cara menggunakan jembatan goyang ini pada dasarnya sama dengan berjalan diatas papan titian, hanya saja dalam permainan ini jembatan akan bergoyang atau bergerak-gerak apabila dilewati oleh anak. Selain itu, alat permainan ini diberi pegangan agar anak tidak terjatuh. Manfaatnya dari kegiatan bermain jembatan goyang adalah dapat melatih keseimbangan anak, konsentrasi, dan kinestetik.Dengan menggunakan alat permainan ini 
dapat memotivasi memotivasi anak untuk tidak takut dalam melewati sebuah rintangan.

5) Bermain Bola dunia juga merupakan pemainan outdoor.Alat permainan ini terbuat dari rangkaian besi yang disusun sedemikian rupa seperti bola dunia dan diberi warna yang menarik. Untuk mendapatkan alat permainan ini bisa dibeli langsung di industri industri pembuatan alat permainan edukatif atau pesan langsung ke jasa pengelasan. Biaya yang dibutuhkan untuk mendapatkan alat permainan bola dunia lebih kurang 1,5 juta. Cara menggunakan alat permainan bola dunia ialah dengan memanjat anak tangga anak tangga yang ada pada bola dunia tersebut. Selain itu, anak juga bisa bergelantungan di masing-masing tanggal secara bebas. Namun demi keamanan sebaiknya orang yang lebih dewasa memberikan pengawasan pada saat bermain. Adapun manfaat dari bermain bola dunia bagi perkembangan anak yaitu dapat melatih kinestetik atau kekuatan otot, kreativitas, dan daya imajinasi anak.

Kegiatan motorik kasar adalah gerakan tubuh yang menggunakan otot-otot besar atau sebagian besar otot untuk untuk melakukan suatu aktivitas tubuh. Aktivitas motorik kasar misalnya: berlari, melompat, mendorong, melempar, menangkap, menendang dan lain sebagainya, kegiatan itu memerlukan dan menggunakan otot-otot besar pada tubuh seseorang. Dave memperjelaskannya dengan mengklasifikasikan domain psikomotorik kedalam lima kategori mulai dari yang paling rendah sampai pada tingkatan yang paling tinggi sebagai berikut:

a. Imitation (peniruan), peniruan yaitu suatu ketrampilan untuk menirukan sesuatu gerakan yang telah dilihat, didengar atau dialaminya. Jadi kemampuan ini terjadi ketika anak mengamati suatu gerakan, dimana ia mulai memberi respon serupa dengan apa yang diamatinya Gerakan meniru ini akan mengurangi koordinasi dan 
control otot-otot syaraf, karenapeniruan gerakan umumnya dilakukan dalam bentuk global dan tidaksempurna. Contoh gerakan ini adalah menirukan gerakan binatang, menirukan suatu gerakan dan menirukan langkah tari.

b. Manipulation (penggunaan konsep), suatu keterampilan untuk menggunakan konsep dalam melakukan kegiatan (gerakan). Keterampilan manipulasi ini menekankan pada perkembangan kemampuan mengikuti pengarahan, penampilan gerakan- gerakan pilihan dan menetapkan suatu penampilan melalui latihan Jadi penampilan gerakan anak menurut petunjuk-petunjuk dan tidak hanya meniru tingkah laku saja. Contohnya adalah menjalankan mesin, menggergaji, melakukan gerakan senam kesegaran jasmani yang didemontrasikan. ${ }^{3}$

c. Presition (ketelitian), keterampilan yang berhubungan dengan kegiatan melakukan gerakan secara teliti dan benar. Keterampilan ini sebenarnya hampir sama dengan gerakan manipulasi tetapi dilakukan dengan kontrol yang lebih baik dan kesalahan yang lebih sedikit. Ketrampilan ini selain membutuhkan kecermatan juga proporsi dan kepastian yang lebih tinggi dalam penampilannya. Responrespon lebih terkoreksi dan kesalahan dibatasi sampai pada tingkat minimum. Contoh gerakan ini adalah gerakan mengendarai/menyetir mobil dengan terampil, berjalan di atas papan titian.

d. Articulation (perangkaian), suatu keterampilan untuk merangkaikan bermacam- macam gerakan secara berkesinambungan. Gerakan artikulasi ini menekankan pada koordinasi suatu rangkaian gerakan dengan membuat urutan tepat dan mencapai yang diharapkan atau konsistensi internal antara

${ }^{3}$ Danang Aji Setyawan, "Kemampuan Motorik Kasar Anak Usia 5-6 Tahun Di TK Negeri Pembina Kota Surakarta”, Penjakora Vol 5 No 1, (April 2008), 21. 
gerakan-gerakan yang berbeda. Contoh ketrampilan gerakan ini adalah mengetik dengan ketepatan dan kecepatan tertentu, menulis, menjahit.

e. Naturalization (kewajaran/pengalamiahan), suatu ketrampilan untuk melakukan gerakan secara wajar. Menurut tingkah laku yang ditampilkan, gerakan ini paling sedikit mengeluarkan energi baik fisik maupun psikis. Gerakan ini biasanya dilakukan secara rutin sehingga telah menunjukkan keluwesannya. Misalnya memainkan bola dengan mahir, menampilkan gaya yang benar dalam berenang, mendemonstrasikan suatu gerakan, pantomim dan sebagainya.

Laura E. Berk menjelaskan perkembangan fisik motorik pada anak usia dini dengan melakukan pengamatan terhadap anak-anak yang sedang bermain di halaman sekolah atau pusat-pusat permainan edukatif lainnya. Hasil pengamatan menunjukkan bahwa ketika anakanak yang sedang bermain, akan muncul adanya keterampilan motorik baru yang masing- masing membentuk pola kehidupannya. Selanjutnya, selama masa pendidikan prasekolah, anak akan terus melakukan intergasi terhadap pola-pola yang semakin kompleks tersebut oleh Laura E. Berk disebut sebagai dinamic system. Kemudian, anak-anak akan mulai mengembangkan keterampilan baru seiring dengan pertumbuhan badan kekuatan fisiknya.

Melalui aktivitas di luar ruangan atau outdoor semua bagian perkembangan anak dapat ditingkatkan. Hal ini terjadi karena aktivitas outdoor melibatkan multi aspek perkembangan anak. Aktivitas outdoor lebih berperan dalam mengintegrasikan sensoris dan berbagai potensi yang dimiliki anak. Hal ini termasuk perkembangan fisik, keterampilan sosial, dan pengetahuan budaya, serta perkembangan emosional dan intelektual. Aktivitas outdoor dapat menjadi tempat yang menunjang kegiatan dan kesempatan belajar bagi anak-anak. Namun, bagi 
kebanyakan anak, peran terpenting aktivitas outdoor adalah untuk merangsang perkembangan serta pertumbuhan fisik. Melalui kegiatan fisik, anak-anak juga mendapatkan kesempatan untuk menjadi lebih sosial, mempelajari peraturan-peraturan, belajar kemandirian,, mengembangkan rasa percaya diri, mengembangakn intelektualnya, dan belajar menyelesaikan permasalahan yang muncul. Sebuah program yang terencana untuk latihan fisik ini merupakan bagian penting dari program masa awal anak-anak. ${ }^{4}$

\section{METODE PENELITIAN}

Penelitian ini menggunakan pendekatan kualitatif dengan jenis penelitian deskriptif, sumber data diperoleh melalui wawancara, observasi, dan dokumentasi. ${ }^{5}$ Informannya adalah kepala sekolah dan guru kelas. Sedangkan pengecekan keabsahan data dilakukan menggunakan triangulasi dengan memanfaatkan penggunaan sumber. ${ }^{6}$

\section{TEMUAN DAN PEMBAHASAN}

Di TK PKK Banjarjo perkembangan motorik kasar anak masih ada yang belum maksimal.Seperti yang telah dijelaskan oleh kepala sekolah bahwa motorik kasar anak di TK PKK Banjarjo masih beragam. Ada yang sudah maksimal dan ada juga yang masih kurang maksimal. Maka dari itu anak-anak masih perlu untuk diawasi dan distimulus agar motorik kasar anak dapat berkembang maksimal. Di sekolah banyak sekali kegiatan-kegiatan yang bisa merangsang motorik kasar anak agar berkembang.Guru juga harus memberikan contoh dan stimulasi agar motorik kasar anak bisa tekoordinasi dan maksimal. Salah satunya yaitu kegiatan bermain outdoor.

\footnotetext{
4 Psikologi Belajar Pendidikan Anak Usia Dini, (Yogyakarta: PT Pustaka Insan Madani, 2010), 67-68.

${ }^{5}$ Sudaryono, Metode Penelitian Pendidikan, (Jakarta: Prenada Media Group, 2016), 87.

${ }^{6}$ Nusa Putra dan Ninin Dwilestari, Penelitian Kualitatif PAUD, (Jakarta: PT Rajagrafindo

Persada,2012), 89.
} 
Bermain adalah dunia anak. Dengan bermain aspek-aspek pekembangan anak akan berkembang dengan sendirinya, seperti sosial emosional, kognitif, motorik kasar, Bahasa dan perkembangan lain. Bemain bisa dilakukan di dalam kelas dan luar kelas. Kegiatan bermain outdoor atau diluar kelas dapat meningkatkan motorik kasar anak. Kegiatan bemain outdoor juga tidak terlepas dari bimbingan dan arahan guru. Guru harus selalu megawasi bagaimana pekembangan anak, apabila anak belum maksimal guru juga harus membimbing agar pekembangannya maksimal.

Kegiatan bermain outdoor di TK PKK Banjarjo sangatlah beragam. Seperti yang dijelaskan oleh Ibu Sumini yaitu bermain APE outdoor seperti : jungkat-jungkit, ayunan dan bola dunia. Bermain jungkat-jungkit, ayunan dan bola dunia dapat meningkatkan motorik kasar anak usia dini. Tetapi permainan tersebut ada bahayanya, karena menggunakan alat permainan yang tinggi dan berbahan besi, jadi harus dengan awasan guru. Di TK PKK Banjarjo permainan tersebut masih belum terlalu banyak hanya ada tiga jenis permainan.

Maka dari itu guru juga mempunyai inisiatif sendiri untuk membuat kegiatan bermain outdoor yang lain untuk media pembelajaran anak. Sebelum adanya permainan-permainan tersebut guru sudah mengajak anak menirukan cara berjalan hewan. Seperti meloncat menirukan cara berjalan kodok, melata cara berjalan ular, berlari dan lain-lain. Selain permainan tersebut masih banyak lagi kegiatan bermain outdoor di TK PKK Banjarjo yaitu membuat topi dari daun kelapa, mengamati tanaman yang ada dikebun dekat sekolah. Karena sekolah berada di pedesaan jadi banyak sekali bahan-bahan alam yang bisa digunakan untuk media pembelajaran anak. Sebenarnya sekolah yang ada dipedesaan banyak sekali bahan yang bisa diambil dari alam, banyak sawah-sawah yang bisa digunakan untuk belajar menanam tetapi ada juga kurangnya, yaitu alat permainan belum memadai seperti yang ada dikota. Guru juga 
mengajak anak-anak untuk bermain permainan tradisional seperti engklek, egrang dan lompat tali. Ibu Wilis mengatakan bahwa permainan tradisional lebih aman. Selain aman digunakan, permainan tradisional juga mudah untuk dibuat dan dicari bahan-bahannya dilingkungan sekitar. Seperti engklek dan egrang yang dibuat dari bambu. Dengan bermain permainan tersebut anak-anak senang diajak untuk ke luar ruangan.Permainan lain yaitu bermain simulasi seperti jalan menuju suatu planet dengan diberi angka setiap langkahnya. Permainan tersebut dibuat sendiri oleh guru dan bisa digunakan didalam ruangan, tetapi dengan ruangan yang besar. Karena anak-anak menyukai hal-hal baru yang belum diketahui dan di mainkan maka guru membuat dan mengajarkan sesuatu yang baru untuk anak. Apabila kegiatan bermain tersebut menyenangkan dan menantang anak akan lebih cepat mengembangkan aspek-aspek perkembangnnya.

Kegiatan bermain outdoor tidak hanya mengembangakan motorik kasar tetapi bisa mengembangkan seluruh aspek perkembangan anak. Seperti yang dilakukan oleh lbu Tumini setiap pagi mengajak anak untuk senam dengan diiringi musik. Dan tidak lupa guru juga mengajak anak berdoa sebelum senam dimulai. Hal tersebut perkembangan moral dan agama anak bisa terstimulasi. Kegiatan tersebut dilakukan sekitar 15-20 menit sebelum pembelajaran di dalam kelas dimulai. Anak-anak sangat antusias mengikuti senam tersebut. Tetapi masih ada anak yang belum menggerakkan seluruh badannya. Anak masih terlihat malu-malu untuk mengikuti kegiatan senam.

Selain kegiatan senam guru juga mengajak anak latihan upacara setiap hari senin pagi. Anak-anak terlihat khidmad mengikuti upacara walaupun masih ada anak yang gerak-gerak sendiri, tetapi guru selalu mengingatkan agar anak mengikuti upacara dengan baik. Dengan melakukan upacara setiap hari senin anak dapat mengetahui lambing bendera indonesi, lagu kebangsaan Indonesia dan sikap yang baik pada 
saat upacara. Setiap seminggu sekali anak juga diajak untuk sholat dhuha berjamaah dimasjid terdekat. Dengan adanya sholat berjamaah anak akan berjalan dari sekolah menuju masjid. Hal tersebut menjadikan motorik kasar anak mulai terstimulasi dan berkembang. Setiap sebulan sekali guru juga mengajak anak untuk melakukan pembelajaran di luar sekolah. Seperti di tempat wisata yang tidak jauh dari sekolah. Anak berangkat dari sekolah menggunakan mobil pick up dengan di damping guru dan orang tua. Guru juga membuat kegiatan dengan orang tua. Kegiatan tersebut diharapkan orang tua lebih dekat da $n$ dapat mengerti betapa pentingnya pendidikan bagi anak. Selain itu juga guru mengajarkan kerjasama antara orang tua dengan anak.

Setiap sebulan sekali guru juga mengajak anak untuk melakukan pembelajaran di luar sekolah. Seperti di tempat wisata yang tidak jauh dari sekolah. Anak berangkat dari sekolah menggunakan mobil pick up dengan di damping guru dan orang tua. Guru juga membuat kegiatan dengan orang tua. Kegiatan tersebut diharapkan orang tua lebih dekat da $\mathrm{n}$ dapat mengerti betapa pentingnya pendidikan bagi anak. Selain itu juga guru mengajarkan kerjasama antara orang tua dengan anak.

Dengan mengacu permendikbud Ibu Tumini selaku guru mengajak anak untuk senam setiap pagi di halaman untuk melatih kelenturan, keseimbangan dan kelincahan anak. Tidak hanya itu senam pagi juga bisa membuat gerakan anak terkoordinasi menirukan guru dala $\mathrm{m}$ senam. Senam tersebut juga menggunakan media musik untuk mengiringinya, selain itu anak juga merasa senang dengan adanya musik. Anak lebih semangat dan antusias menirukan gerakan guru yang memberi contoh didepan. Guru juga memberikan gerakan-gerakan yang berbeda agar anak tidak bosan. Dan juga dengan musik yang berbeda. Ada juga senam yang menggunakan media tempat nasi, anak disuruh untuk membawa dari rumah. 
Pada saat senam anak juga diajari untuk baris berbaris dengan rapi. Seperti tangan siap, lencang depan, lencang kanan dan lain-lain. Pada saat baris ada juga anak yang tidak mau mengikuti arahan guru dan tidak mau ikut senan. Tetapi guru sebisa mungkin mengajak dan membujuk anak untuk ikut. Seperti memanggil anak yang tidak mau senam dengan bernyanyi bersama-sama dan menyebut namanya. Setelah itu anak tersebut malu-malu dan bisa mengikuti senam dan baris seperti yang lain. Senam juga bisa melatih dan menstimulus motorik kasar anak melalui gerakan-gerakan yang diajarkan. Karena senam juga bisa menggerakkan semua anggota badan anak. Jadi dengan senam motorik kasar anak bisa berkembang. Anak-anak juga senang diajak untuk keluar kelas dan senam menggunakan musik. Setelah selesai senam guru juga memberikan tebak-tebak an sederhana, seperti benda yang berawalan huruf $A$ dan lain sebagainya. Anak yang menjawab dengan benar dan cepat maka akan masuk kelas pertama.

Selain senam implementasi kegiatan bermain outdoor dalam mengembangkan motorik kasar anak di TK PKK Banjarjo adalah bermain APE outdoor yaitu jungkat-jungkit, ayunan, dan bola dunia. Ibu Wilis membiarkan anak-anak bermain dihalaman dengan alat permainan yang ada diluar setiap istirahat dan sebelum masuk kelas. Tetapi guru juga selalu mengawasi anak pada saat bermain, karena alat permainan tersebut tinggi dan terbuat dari besi.

Alat permainan jungkat-jungkit harus dimainkan minimal 2 dengan cara salah satu anak menggenjot agar ada gerakan naik dan turun. Permainan tersebut mengembangkan kinestetik, konsentrasi, keseimbangan dan kelincahan anak. Selain itu juga otot tangan dan kaki anak akan lebih kuat. Sedangakan alat permainan ayunan di TK PKK Banjarjo berbentuk kursi tetapi bisa diayunkan pelan-pelan. Jadi anak bisa bermain sendiri di ayunan. Tetapi anak juga harus menjaga keseimbangan agar tidak jatuh dan berpegangan pada tali atau rantai 
ayunan.Permainan tersebut selain mengembangkan motorik kasar anak juga mengembangkan ketangkasan anak. Selanjutnya yaitu alat permainan bola dunia anak akan belajar memanjat bola tersebut. Anak dapat mengembangkan kreativitas, daya imajinasinya dan otot anak akan menjadi lebih kuat.

Dengan bermain permainan tersebut anak akan bisa mengkoordinasikan motoriknya sendiri. Karena dihalaman anak juga bisa berlari, melompat sesuai yang disenangi. Tetapi pada saat istirahat masih ada anak yang belum mau bermain dengan temannya di halaman. Jadi guru juga mengajak bermain permainan lain di depan kelas. Agar motorik kasar anak tersebut tidak ketinggalan dengan anak lain. Guru juga mencoba membeitahu anak-anak untuk mengajak anak tersebut bermain dengan mereka di halaman.

Implementasi kegiatan bermain outdoor dalam mengembangkan motorik kasar di TK PKK Banjarjo yaitu dengan senam dan bermain permainan yang ada dihalaman. Kegiatan tersebut dapat menstimulus perkembangkan motorik kasar anak agar dapat berkembang sesuai standar perkembangan. Dengan senam setiap pagi gerakan tangan kaki dan badan anak lama kelamaan akan terkoordinasi dengan maksimal. Karena senam tersebut dilakukan setiap hari dan menjadi pembiasaan anak untuk menggerakkan seluruh badannya. Selain menstimulus perkembangan motorik kasar, senam juga bisa mengembangkan kreatifitas anak karena harus memadukan anatara gerakan dan musiknya.

Selain senam yaitu dengan cara membiarkan anak bermain APE yang ada di halaman setiap sebelum masuk kelas dan setiap istirahat setelah pembelajaran di dalam kelas. Dengan bermain jungkat-jungkit, ayunan dan bola dunia anak juga bisa menstimulus perkembangan motorik kasar dengan sendirinya, karena permainan tersebut anak bisa 
memanjat, otot menjadi kuat sehingga dapat menggerakkan tangan dan kakinya dengan baik dan lain sebagainya.

Jadi dengan pembiasaan-pembiasaan kegiatan bermain tersebut anak akan lebih mudah untuk mengembangkan motorik kasarnya. Karena kegiatan tersebut dilakukan sehari-hari dengan arahan dan bimbingan guru. Motorik kasar anak akan semakin berkembang dan terkoordinasi dengan baik. Selain mengembangkan motorik kasar, kegiatan tersebut juga mengembangakan perkembangan yang lainnya. Faktor pendukung dalam mengimplementasikan kegiatan bermain outdoor untuk mengembangkan motorik kasar di TK PKK Banjarjo menurut Ibu Wilis yaitu dari semangat anak-anak yang setiap hari masuk sekolah dan mau mengikuti pembelajaran yang ada. Apabila anak antusias mengikuti kegiatan yang ada maka hal tersebut sudah merupakan faktor pendukung untuk guru dalam memberikan suatu pembelajaran. selain itu, guru juga akan semangat dan senang membuat sesuatu yang menarik untuk pembelajaran.

Guru juga membuat kegiatan-kegiatan dan alat permainan yang kreatif dan menarik untuk menstimulus perkembangan motorik kasar anak. Dalam hal pemikiran, guru di TK PKK Banjarjo sudah baik, jadi guru bisa membuat alat permainan sederhana sendiri. Alat permainan yang dibuat juga mengacu pada faktor perkembangan anak. Faktor pendukung lain yaitu motivasi dari kepala sekolah dan sesama guru juga menjadi penyemangat guru dalam mengimplementasikan kegiatan bermain outdoor tersebut. Selain itu juga kekompakan guru dalam segala hal akan menjadi tujuan tercapai.

Perkembangan motorik kasar harus distimulus menggunakan alat permainan. Sedangkan di TK PKK Banjarjo alat pemainan outdoor masih sangat minim. Seperti yang peneliti lihat alat permainan outdoor masih ada tiga macam, yaitu jungkat-jungkit, ayunan dan bola dunia. Maka dari 
itu guru juga berinisiatif untuk membuat alat permainan sederhana agar pembelajaran berjalan dengan lancar. Permainan tesebut adalah permainan tadisional seperti engklek, egrang dan ular naga. Permainan tradisional dapat mengembangakan motorik kasar anak, seperti meloncat, berjalan dan berlari.

Faktor pendukung pasti berkaitan dengan faktor penghambat. Faktor penghambat di TK PKK Banjarjo dalam mengimplementasikan kegiatan bermain outdoor untuk mengembangkan motorik kasar adalah faktor pembiayaan. Faktor tersebut yang menjadikan perkembangan anak menjadi kurang maksimal, karena biaya untuk alat pemainan yang tidak ada. Jika mau bermain anak harus mengantri untuk permainan outdoor tersebut, karena APE yang ada di luar masih belum terfasilitasi dengan baik. Selain itu juga sekolah ini berada di pedesaan yang mayoritas ekonomi wali murid yaitu petani. Faktor ekonomi tersebut mengakibatkan wali murid masih ada yang menunggak SPP anak, karena penghasilan belum cukup untuk membayar SPP sekolah.

Sekolah tersebut juga dibawah naungan yayasan PKK Desa jadiapabila membutuhkan dana pihak sekolah sungkan untuk meminta. Karena belum tentu dana tersebut ada. Sebenarnya TK PKK Banjarjo juga memperoleh dana BOP, tetapi belum mencukupi untuk membeli keperluan sekolah selama 1 tahun. Guru sebisa mungkin untuk menghemat dan membeli keperluan yang sangat penting saja.

Faktor penghambat lain yaitu halaman sekolah yang kurang memadai. Halaman sekolah belum dipaping dan masih ada kerikil-kerikil kecil. Kerikil tersebut sangat berbahaya untuk anak, karena anak-anak banyak yang bermain dihalaman apalagi permainan-permainan berada dihalaman. Halaman juga panas dan belum ada pohon yang rindang agar halaman menjadi sejuk, tetapi sudah ada tanaman disekitar 
halaman yang ditanam. Walaupun belum ada pohon harusnya atap diberi jarring-jaring agar tidak terlalu panas.

\section{KESIMPULAN}

1. Bentuk-bentuk kegiatan bermain outdoor di TK PKK Banjarjo yaitu :

a. Bermain APE outdoor seperti jungkat-jungkit, ayunan dan bola dunia.

b. Senam dengan diiringi musik setiap pagi.

c. Bermain alat permainan tradisional seperti engklek, egrang dan ular naga.

d. Mengamati tanaman di kebun.

e. Menirukan cara binatang berjalan.

f. Mengajak jalan-jalan ke wisata terdekat.

2. Implementasi kegiatan bermain outdoor dalam mengembangkan motorik kasar di TK PKK Banjarjo Pudak Ponorogo. Implementasi kegiatan bermain outdoor dalam mengembangkan motoric kasar di TK PKK Banjarjo ada 2, yaitu dengan cara anak dibiarkan bermain dihalaman dan bermain APE yang ada dihalaman. Selain itu anak juga bisa belari-larian dan melompat agar bisa mengembangkan dan menstimulus motorik kasarnya. Yang ke dua yaitu dengan cara senam dengan musik setiap pagi agar badan dapat bergerak semua.

3. Faktor Pendukung Dan Penghambat Dalam Mengimplementasikan Kegiatan Bermain Outdoor Untuk Mengembangkan Motorik Kasar Di TK PKK Banjarjo Pudak Ponorogo. Faktor Pendukung Dalam Mengimplementasikan Kegiatan Bermain Outdoor Untuk Mengembangkan Motorik Kasar Di TK PKK Banjarjo yaitu semangat anak-anak mengikuti pembelajaran dengan antusias, selain itu juga motivasi dari kepala sekolah dan kekompakan guru untuk mencapai tujuan bersama. Sedangakan faktor penghambatnya yaitu faktor pembiayaan terhadap alat permainan.Faktor penghambat lain yaitu halaman yang kurang memadai karena halaman panas dan belum ada pohon yang rindang. 


\section{DAFTAR PUSTAKA}

https://www.paud.id/2015/09/pengertian-sarana-bermain-luar-ruanganaud.html

Aji Setyawan Danang. Kemampuan Motorik Kasar Anak Usia 5-6 Tahun Di TK Negeri Pembina Kota Surakarta", Penjakora Vol 5 No 1, April 2008.

Fadlillah. , Bermain Dan Permainan Anak Usia Dini. Jakarta: Kencana, 2017.

Putra Nusa dan Dwilestari Ninin.Penelitian Kualitatif PAUD. Jakarta:

PT Rajagrafindo Persada, 2012.

Sudaryono. Metode Penelitian Pendidikan. Jakarta: Prenada Media Group, 2016.

Suyadi.Psikologi Belajar Pendidikan Anak Usia Dini. Yogyakarta: PT Pustaka Insan Madani, 2010. 